\title{
Incidence, Risk Factors and Pregnant Outcomes of Premature Rupture of Membranes: A Cross Section Study
}

\author{
MOHAMED EL-HUSSENY RADWAN, M.D. \\ The Department of Obstetrics \& Gynecology, Faculty of Medicine, Zagazig University, Zagazig 44519, Egypt
}

\begin{abstract}
Background: Premature births are responsible for 27.0 per cent of annual child deaths globally, 70.0 per cent of prenatal mortality in developed countries and 50.0 per cent of neurological disorders. Obstetric risk factors include: Cervical incompetence, multiple gestation, limited birth cycles, history of abortion, premature membrane breakup, and prior preterm labour. In the meantime, pregnancy conditions such as respiratory disorders and hypertension are the most common direct causes of preterm birth. Bleeding during labour, polyhydramnios or oligohydramnios, foetal abnormalities including, in particular, numerous organ systems and central nervous system abnormalities.
\end{abstract}

Aim of Study: The purpose of this research was to measure the prevalence rate of PPROM among pregnant women in order to identify risk factors associated with PROM and fetal/neonatal outcomes.

Patients and Methods: Is to calculate the incidence rate of PPROM among pregnant women attending Zagazig University hospital, and to identify the fetal/neonatal outcome and potential factors associated with poor fetal/neonatal outcome.This is a cross-section study, performed at the ER Department of Zagazig University Hospitals for Vaginal Delivery, from July 2020 to January 2021, of 138 women with premature membrane abduction.

Result: Risk factors for cases were 30 with no risk factor $(21.7 \%), 16$ with prior PROM $(11.6 \%), 12$ with multipregnancy $(8.7 \%), 24$ with Antepartum (17.4\%). There was a statistically meaningful disparity between the outcomes of the infants in relation to the risk factors of the mothers. In the cases of the infants of strong APGAR there was a latent period of $8.89( \pm 6.64 \mathrm{SD})$ for cases where the infants required an $\mathrm{O} 2$ incubator there was a latent period of 9.73 ( $\pm 5.69 \mathrm{SD})$. There was no statistically significant difference between the outcomes of the infants in relation to the latent period.

Conclusion: From this study, it can be inferred that low socio-economic, younger, illiterate partitioning women have been shown to cause a rise in PPROM. Such hazards may impact both maternal and neonatal outcomes such as infection, maternal pain, foetal distress, increased surgical delivery, and the need for neonatal intensive care in more than 50 per cent of neonates.

Correspondence to: Dr. Mohamed El-Husseny Radwan, E-Mail: hussenyradwan@gmail.com
Key Words: Rupture of membranes - Incidence - Risk factors - Premature.

\section{Introduction}

PREMATURE membrane rupture (PROM) is generally characterised as membrane rupture at any point prior to the initiation of uterine contractions. PROM, which occurs before 37 weeks of gestation, is referred to as preterm premature membrane rupture (PPROM), while PROM, which occurs after 37 weeks of gestation, is referred to as the term premature membrane rupture. The latent phase is known as the duration of the rupture of the membranes until the onset of true labor [1].

The prevalence of PROM varies in various countries and populations, and several aspects have an effect on its incidence. Its aetiology is also dynamic and multi-factorial. Two thirds of PROM events arise unexpectedly or for unexplained causes. However, most examples are attributable to structural deficiencies in the membrane due to loss of collagen material in the membrane and to the protrusion of the membrane due to isthmus cervical incompetence, and activation of catabolic enzymes such as collagenase [2]

Trigger factors for PROM include parental, and the experience of PROM in past pregnancies (a risk of recurrence of 16 to 32 per cent compared to a risk of 4 per cent in uncomplicated pregnancy), menstrual bleeding before birth, long-term use of hormones, vascular collagen disorders such as Ehlers Danlos syndrome, systemic lupus erythematosus, drug abuse, anemia [3].

PPROM is associated with maternal morbidity and mortality rates of more than $20 \%$ and findings are largely based on gestational age at birth. The key to reducing the adverse effects of PPROM is early diagnosis, admission and initiation of antibiotic therapyIt'scoverage [4]. 


\section{Patients and Methods}

This study was a cross sectional study carried out at ER Department of Zagazig University Hospitals. From July 2020 till January 2021. (Sample was 138 women). An informed verbal consent from the participants was taken.

\section{Inclusion criteria:}

1- Patients presented by PROM.

2- Gestational age ( 2 nd and 3 rd trimesters).

3- Paitents presented by chorioaminities (fetal tachycardia-maternal fever).

4- Clear amniotic fluid.

5- No contraction.

\section{Exclusion criteria:}

1- Rapture of membrane (post date).

2- Congenital fetal anomalies.

3- Placental abnormalities.

4- Presence of fetal stress sign.

5- Meconuim liquor stain.

6- Ante partum hemorrhage.

All patients were subjected to the following:

Clinical assessment:

- History taking

- General and Obstetric examination

- Investigation:

- CBC

- CRP

- Amniotic fluid culture and urine culture were done.

Foetal distress cases were delivered by emergency caesarean section.

Patients were followed till their delivery and postnatally and data regarding mode of delivery.

Maternal outcomes: Mode of delivery (spontaneous vaginal or CS delivery), presence of clinical chorioamnionitis which is characterized by maternal fever $\left(>39^{\circ} \mathrm{c}\right)$ accompanied by at least two of the following signs: Maternal or fetal tachycardia, maternal leukocytosis, uterine tenderness, or foulsmelling amniotic fluid.

Fetal/Neonatal outcome: Birth weight (in Kgs), alive and well, alive but needed Neonatal intensive care unit (NICU) admission, neonatal death or others (e.g., neonatal infection jaundice).
Statistical analysis:

Analysis of data was done using Statistical Program for Social Science version 20 (SPSS Inc., Chicago, IL, USA).

\section{Results}

Table (1) shows that for studied the studied cases $(n=138)$ had mean age $26.55( \pm 6.15 \mathrm{SD})$ with range (17-43) and median 26 (24-31). The previous table shows that the Gravidity of the cases $(n=138)$ had mean of $2.78( \pm 1.82 \mathrm{SD})$ with range of (1-8) and parity mean of $1.3( \pm 1.33 \mathrm{SD})$ with range $(0$ $6)$. There were 98 cases (previously pregnant) had abortion between (0-6) times with average 0.69 $( \pm 1.09$ SD). The Gestational age at PROM (wks.) of studied cases was 34.57 ( $\pm 2.7 \mathrm{SD}$ ) with range (28-39.71), latent period (days) was $9( \pm 6.16 \mathrm{SD})$ with range (2-42) and the gestational age at termination (wks.) was $35.85( \pm 2.57 \mathrm{SD})$ with range (29.14-40.29). Table (2) shows that BMI (body mass index) of the cases $(n=138)$ had mean 26.5 with range (24-30). The risk factors of the cases were 30 with no risk factor $(21.7 \%), 16$ with previous PROM (11.6\%), 12 with multi pregnancy (8.7\%), 24 with Antepartum (17.4\%), 32 with infections $(23.2 \%)$ and 24 with chronic diseases $(17.4 \%)$. Table (3) shows that among the studied cases there were 92 mother gave birth of healthy babies with good APGAR score (66.7\%), 30 with babies needed $\mathrm{O} 2$ incubators $(21.7 \%)$ and 16 with babies were put on ventilators $(11.6 \%)$. The outcome of mothers there were 104 (75.4\%) with C.S, $34(24.6 \%)$ with NVD, 132 mother with no bad outcomes and 2 with chorioamnionitis, 4 (2.8\%) with puerperal sepsis. Table (5) shows that among cases with no risk factors 22 gave birth of healthy babies with good APGAR, 4 with babies needed $\mathrm{O} 2$ incubator and 4 with babies were put on ventilator.

Among cases with Previous PROM 8 gave birth of healthy babies with good APGAR, 2 with babies needed $\mathrm{O} 2$ incubator and 6 with babies were put on ventilator.

Among cases with Multiple pregnancy 0 gave birth of healthy babies with good APGAR, 8 with babies needed $\mathrm{O} 2$ incubator and 4 with babies were put on ventilator. Among cases with Antepartum 20 gave birth of healthy babies with good APGAR, 4 with babies needed $\mathrm{O} 2$ incubator and 0 with babies were put on ventilator.Among cases with Infections 26 gave birth of healthy babies with good APGAR, 4 with babies needed $\mathrm{O} 2$ incubator and 2 with babies were put on ventilator.Among cases with Chronic disease 8 gave birth of healthy 
babies with good APGAR, 8 with babies needed $\mathrm{O} 2$ incubator. This table showed that there was statistically significant difference between outcome of the babies as regard Risk factors of the mothers. Table (6) shows that for cases with babies of good APGAR there Latent Period was $8.89( \pm 6.64 \mathrm{SD})$ with range (3-42) and median 7.
For cases with babies needed $\mathrm{O} 2$ incubator there Latent Period was $9.73( \pm 5.69 \mathrm{SD})$ with range (3-22) and median 7. For cases with babies were put on ventilator there Latent Period was 8.25 $( \pm 4.37 \mathrm{SD})$ with range (3-15) and median 7 . There was no statistically significant difference between the outcome of babies as regard the Latent period.

Table (1): Descriptive analysis of the studied cases according to basic characteristic data of the studied groups $(n=138)$.

\begin{tabular}{lllll}
\hline & No. & Min. - Max. & Mean \pm SD & Median (IQR) \\
\hline Age (years) & 138 & $17.0-43.0$ & $26.55 \pm 6.15$ & $26.0(24.0-31.0)$ \\
BMI & 138 & $24-30$ & $26.5 \pm 2.1$ & \\
Gravidity & 138 & $1.0-8.0$ & $2.78 \pm 1.82$ & $2.0(2.0-4.50)$ \\
Parity & 138 & $0.0-6.0$ & $1.30 \pm 1.33$ & $1.0(1.0-3.0)$ \\
Abortion & 98 & $0.0-6.0$ & $0.69 \pm 1.09$ & $0.0(0.0-1.0)$ \\
Gestational age at PROM (wks.) & 138 & $28.0-39.71$ & $34.57 \pm 2.70$ & $35.0(32.36-36.57)$ \\
Latent period (days) & 138 & $2.0-42.0$ & $9.0 \pm 6.16$ & $7.0(6.0-12.0)$ \\
Gestational age at termination (wks.) & 138 & $29.14-40.29$ & $35.85 \pm 2.57$ & $36.64(33.79-37.57)$ \\
\hline
\end{tabular}

Table (2): Distribution of the studied cases to risk factor $(\mathrm{n}=138)$

\begin{tabular}{lcc}
\hline Risk factor & No. & $\%$ \\
\hline None & 30 & 21.7 \\
Previous PROM & 16 & 11.6 \\
Multiple pregnancy & 12 & 8.7 \\
Antepartum & 24 & 17.4 \\
Infections & 32 & 23.2 \\
Chronic disease & 24 & 17.4 \\
\hline
\end{tabular}

Table (3): Distribution of the studied cases according to outcome of baby.

\begin{tabular}{cccc}
\hline & Score (7-10) & No. & $\%$ \\
\hline Good Apgar score: & & & \\
At 1 st minutes & $7-8$ & 92 & 66.7 \\
At 5st minutes & $8-10$ & & \\
Fetus need NICU: & & & \\
O2 & $>7$ & 30 & 21.7 \\
On ventilator & $>4$ & 16 & 11.6 \\
\hline
\end{tabular}

Table (4): Distribution of the studied cases according to outcome of mother.

\begin{tabular}{lll}
\hline & No. & $\%$ \\
\hline C.S & 104 & 75.4 \\
NVD & 34 & 24.6 \\
Chorioamnionitis & 2 & 1.4 \\
Puerperal sepsis & 4 & 2.8 \\
Assisted delivery & 0 & 0 \\
NAD (Nothing Appear Dignostic) & 132 & 95.6 \\
\hline
\end{tabular}

Table (5): Relation between outcome and risk factor.

\begin{tabular}{|c|c|c|c|c|c|c|c|}
\hline \multirow{3}{*}{$\begin{array}{l}\text { Risk } \\
\text { factor }\end{array}$} & \multicolumn{5}{|c|}{ Outcome } & \multirow{3}{*}{$x^{2}$} & \multirow{3}{*}{$\mathrm{MC}_{\mathrm{p}}$} \\
\hline & \multicolumn{2}{|c|}{$\begin{array}{c}\text { Good } \\
\text { Apgar } \\
\text { score } \\
(\mathrm{n}=92)\end{array}$} & \multicolumn{2}{|c|}{$\begin{array}{c}\mathrm{O} 2 \\
\text { Incubator } \\
(\mathrm{n}=30)\end{array}$} & $\begin{array}{c}\text { On } \\
\text { ventilator } \\
(n=16)\end{array}$ & & \\
\hline & No. & $\%$ & No. & $\%$ & No. $\%$ & & \\
\hline None & 22 & 23.9 & 4 & 13.3 & $25.0 \quad 20$ & $0.997 *$ & $0.004 *$ \\
\hline $\begin{array}{c}\text { Previous } \\
\text { PROM }\end{array}$ & & 8.7 & 2 & 6.7 & $\begin{array}{ll}6 & 37.5\end{array}$ & & \\
\hline $\begin{array}{l}\text { Multiple } \\
\text { pregnancy }\end{array}$ & 0 & 0.0 & 8 & 26.7 & $4 \quad 25.0$ & & \\
\hline Antepartum & 20 & 21.7 & 4 & 13.3 & $\begin{array}{ll}0 & 0.0\end{array}$ & & \\
\hline Infections & 26 & 28.3 & 4 & 13.3 & 12.5 & & \\
\hline $\begin{array}{l}\text { Chronic } \\
\text { disease }\end{array}$ & 16 & 17.4 & 8 & 26.7 & 0.0 & & \\
\hline \multicolumn{8}{|c|}{ Table (6): Relation between outcome and latent period (days). } \\
\hline \multirow[b]{2}{*}{$\begin{array}{l}\text { Latent } \\
\text { period } \\
\text { (days) }\end{array}$} & \multicolumn{5}{|c|}{ Outcome } & & \\
\hline & & $\begin{array}{l}\text { lood } \\
\text { pgar } \\
\text { core } \\
=92 \text { ) }\end{array}$ & & $\begin{array}{l}\mathrm{O} 2 \\
\text { cubator } \\
\mathrm{n}=30 \text { ) }\end{array}$ & $\begin{array}{c}\text { On } \\
\text { ventilator } \\
(n=16)\end{array}$ & r & $p$ \\
\hline Min. - Max. & $3.0-$ & 42.0 & & -22.0 & $2.0-15.0$ & 0.595 & 0.743 \\
\hline Mean \pm SD. & 8.89 & \pm 6.64 & & $7 \pm 5.69$ & $98.25 \pm 4.37$ & & \\
\hline Median & 7.0 & & 7.0 & & 7.0 & & \\
\hline
\end{tabular}

H: H for Kruskal Wallis test.

$p: p$-value for association between different categories.

$*$ : Statistically significant at $p \leq 0.05$. 


\section{Discussion}

The key objectives of this research were to determine the risk factors in women with PROM, to assess the incident rate of PROM and to assess the outcome of PROM in Zagazig University Hospitals. A cross-section research was performed at Zagazig University Clinics, including 138 women with PROM. The length of the study varies from 6 to 12 months.

\section{The main results of the study were as following:}

The studied cases $(\mathrm{n}=138)$ had mean age 26.55 $( \pm 6.15 \mathrm{SD})$ with range (17-43) and median 72 (24$31)$, there were 68 cases had age less than or equal to 25 years $(49.3 \%)$ and 70 cases had age more than 25 years $(50.7 \%)$. Our results are in agreement with study of Negara et al., 2017 as they reported that in this study it was found that the mean age of the case group was $26.59 \pm 6.49$ years [5]

In the study by Budijaya \& Surya, 2016, The frequency of PROM was found to be the most frequent in the 21-30 year age range, with 116 cases (54.72 per cent) of 212 PROM cases, including term pregnancy and preterm pregnancy [6] .

The study by Linehan et al., (2016) The largest prevalence of PROM was observed in the 18-35 age range $(74.6 \%)$ of the 202 PROM patients [7] Singh et al., (2015), reported the most preterm PROM cases in the 20-30 year age range. The present analysis indicates that the Gravity of Cases $(\mathrm{n}=69)$ had a mean of $2.78( \pm 1.82 \mathrm{SD})$ with a range of (1-8) and a mean of parity of $1.3( \pm 1.33 \mathrm{SD})$ with a range of 1.3. (0-6). There have been 49 cases (previously pregnant) had abortion. The gestational age at PROM (wks.) of the cases analysed $(n=69)$ was $34.57( \pm 2.7 \mathrm{SD})$ with range (28$39.71)$, the latent time (days) was 9 ( $\pm 6.16 \mathrm{SD})$ with range (2-42) and the gestational age at termination (wks.) was 35.85 ( $\pm 2.57 \mathrm{SD})$ with range (242). (29.14-40.29). Of the cases examined, 63 cases had a single child (91.3 per cent), 5 cases had twins (7.2 per cent) and 1 case had triplets (1.4 percent). There were 43 male children (56.6 percent) [8] .

Based on parity, study by Emechebe et al., 2015 The majority of PROM cases got were nullipara (52 percent), parity 1-4 (44 percent) [9]. Okeke et al., 2014 reported that the majority of PROM cases were nullipara (29.1 per cent), parity 2 (26.6 per cent), parity 1 (19 per cent) [10].

The latest research indicates that the cases analysed $(n=138)$ had 104 cases of caesarean delivery $(75.4 \%)$ and 34 cases had regular vaginal delivery (24.6 percent).
Our findings are confirmed by a study by SaeLin \& Wanitpongpan, 2019, which stated that $39.7 \%$ of their cases had caesarean section [11]. As a result, maternal and neonatal mortality in the country declined from 49 per 1,000 and 871 per 100,000 in 2000 GC to 28 and 420 in 2014 GC. Despite these achievements, maternal and neonatal death remains one of the highest in the world. PROM is one of the causes of prematurity and inflammation. [12]. In the research in our hands, among the cases surveyed, 92 mothers gave birth to healthy infants with a strong APGAR score (66.7 per cent), 30 infants needed o2 incubators (21.7 per cent) and 16 infants were kept on ventilators (11.6 percent). There were 136 mothers with no negative results and 2 with chorioamnionitis.

Our findings are backed by a report by Bouvier et al., 2019 as they Complications consistent with PPROM have been identified as oligohydramnios [aOR: 4.17 (2.37-7.35)], abruptio placentae [aOR: 4.28 (1.87-9.78)], caesarean [aOR: 1.41 (1.021.96)], APGAR 5'<4 [aOR: 23.32 (7.04-77.19)], birth weight <2500 g [aOR: 47.74 (32.52-70.08)], stillbirth $(1.1 \%$ in PPROM group versus 0 percent in control group, $p<0.0001$ ), neonatal jaundice [aOR: 3.25 (2.20-4.80)] [13].

Everest et al., 2008 The majority of live born babies were observed to need intensive neonatal treatment, including mechanical ventilation (78\%) if a membrane rupture happened before 24 weeks of gestation and had a latent duration of 14 days. Airleak occurred in $25 \%$ of the survivors and $67 \%$ of those who perished. Of the survivors, 43 per cent needed extra oxygen at 36 weeks of postmenstrual age and 10 had pulmonary problems ashypoplasia [14]. Prediction and avoidance of PROM will provide the best way to escape risks. Risk factors for PROM include preterm birth, tobacco consumption, polyhydramnios, urinary and sexually transmitted illness, past PROM, pregnancy-related work, low body mass index, bleeding, low socioeconomic status [15]

The present research indicates that the risk factors for cases were 30 with no risk factor (21.7\%), 16 with prior PROM (11.6\%), 12 with multi-pregnancy $(8.7 \%), 24$ with Antepartum (17.4\%), 16 with infections (23.2\%) and 24 with chronic diseases (17.4 percent).

Among cases with no risk factors, 22 gave birth to healthy infants with strong APGAR, 4 with the baby needed $\mathrm{O} 2$ incubator and 2 with the baby were given ventilator. Of the cases where Prior PROM 8 had given birth to stable children with strong APGAR, 2 had an $\mathrm{O} 2$ incubator for infants 
and 6 had a ventilator for infants. Among cases of multiple pregnancy, 0 gave birth to healthy infants with strong APGAR, 8 with the baby needed $\mathrm{O} 2$ incubator and 4 with the baby were placed on the ventilator. Of the cases of Antepartum 20, stable children were born with good APGAR. Among the cases of Infection 26, stable babies with strong APGAR were giving birth, 4 with the baby wanted o2 incubator and 2 with the baby were placed on the ventilator. In cases of Chronic Disease 16, stable infants with strong APGAR were giving birth, 4 with the baby needed $\mathrm{O} 2$ incubator and 0 with the baby were placed on the ventilator. There was a statistically important difference between the result of the baby in relation to Risk factors of the mothers.

Our findings are confirmed by a review by Zhou et al., 2014, which stated that literature from the USA and China has indicated that preterm birth history is a risk factor for premature membrane rupture. However, this research did not show any important correlation between preterm birth history and premature membrane breakup. This is in line with other researchers from Lithuania, India, Pakistan and Uganda [16,17] .Several studies from USA, Sweden, India, Thailand, Egypt, Nigeria and Uganda revealed that previous PROM was a significant risk factor for premature rupture of membranes [18].

Assefa et al., 2018 An irregular vaginal discharge has been found to have a strong correlation with the onset of PROM. People that had irregular vaginal discharge in the pregnancy index were 3.31 times more likely to develop PROM. This is in line with the research carried out in Uganda and Egypt $[\mathbf{1 9 , 2 0 ]}$. Infections, a history of prematurity and recurrent pregnancy are known risk factors for both PPROMs. The correlation of broad prematurity infection is compatible with recent theories that present PPROM infection as a downstream occurrence rather than a causal factor [21,22]. Although infection has been accepted as a major risk factor of PPROM, many of previous preventive strategies by antibiotics seemed unsatisfactory and did not help to reduce the incidence $[\mathbf{2 3 , 2 4 ]}$.

The present research indicates that the latent time was 8.89 ( $\pm 6.64 \mathrm{SD})$ with range (3-42) and median 7 for cases with strong APGAR infants. In cases where infants needed an $\mathrm{O} 2$ incubator, the latent time was 9.73 ( $\pm 5.69 \mathrm{SD})$ with range (3-22) and median 7 . In cases with children, the latent time was $8.25( \pm 4.37 \mathrm{SD})$ with a spectrum (3-15) and a median of 7 . There was no statistical warning. The complications associated with PPROM, such as oligohydramnios, abruption placentae, APGAR $5^{\prime}<4$, weight $<2500 \mathrm{~g}$, stillbirth, neonatal jaundice, and hospitalization of neonates in NICU, are not related to PPROM per se but are associated with prematurity $[\mathbf{2 5 , 2 6 ]}$. There was an increased risk of PROM neonates continuing to be treated in a hospital, thereby prolonging the time of hospitalisation and rising in-hospital expenses. The period of neonate hospitalisation was extended by 20.0 per cent in full-term infants and 25.1 per cent in preterm infants with PROM and the overall in-hospital expense rose by 30.5 per cent in full-term infants with PROM and by 60.0 per cent in preterm infants with PROM.

\section{Conclusion:}

From this study, it can be inferred that low socio-economic, younger, illiterate partitioning women have been shown to cause a rise in PPROM. Such hazards may impact both maternal and neonatal outcomes such as infection, maternal pain, foetal distress, increased surgical delivery, and the need for neonatal intensive care in more than 50 per cent of neonates.

\section{Compliance with ethical standards:}

Disclosure statement: No potential conflict of interest was reported by the authors.

Informed consent: Informed consent was obtained from all participants in the study.

Ethical approval: All procedures performed in studies were approved with ethical standards of the Ethical Committee of The Department of Obstetrics and Gynecology, Faculty of Medicine, Zagazig University.

Funding: No funding was taken from agencies in the public, commercial, or not-for-profit sectors

\section{Acknowledgements:}

Special thanks to the patients and their families for their support of our work. Also, the authors appreciate the support from labor room, neonatology \& ultrasound staff of Zagazig University Maternity Hospital for the outstanding support during the entire study.

\section{References}

1- KIVER V., BOOS V., THOMAS A., HENRICH W. and WEICHERT A.: Perinatal outcomes after previable preterm premature rupture of membranes before 24 weeks of gestation. Journal of Perinatal Medicine, 46 (5): 555-565, 2018.

2- MATTUIZZI A., SAUVESTRE F., ANDRÉ G., POINGT M., CAMBERLEIN C., CARLES D. and LAZARO E.: Adverse perinatal outcomes of chronic intervillositis of 
unknown etiology: An observational retrospective study of 122 cases. Scientific Reports, 10 (1): 1-9, 2020.

3- CONG Y.E., JUN-RONG W.A.N.G., MING-HUI F.A.N. and YU-BO H.U.: Retrospective Analysis of Risk Factors for Length of Stay in Intensive Care Unit and Survival Outcome from Premature Infants with Premature Rupture of Membranes. DEStech Transactions on Biology and Health, (icmsb), 2018.

4- DUNCAN, et al.: Fetal pulmonary artery acceleration/ejection time prognostic accuracy for respiratory complications in preterm prelabor rupture of membranes. J. Matern Fetal Neonatal Med., Jun., 33 (12): 2054-2058, 2020.

5- NEGARA K.S., SUWIYOGA K., ARIJANA K. and TUNAS K.: Role of Caspase-3 as risk factors of premature rupture of membranes. Biomedical and Pharmacology Journal, 10 (4): 2091-2098, 2017.

6- BUDIJAYA and SURYA NEGARA: Profil Persalinan Dengan Ketuban Pecah Dini Di RSUP Sanglah Denpasar Periode 1 Januari - 31 Desember 2015, Laporan PenelitianDeskriptif, 2016.

7- LIANG H., XIE Z., LIU B., SONG X. and ZHAO G.: A routine urine test has partial predictive value in premature rupture of the membranes. Journal of International Medical Research, 0300060519841160, 2019.

8- SINGH D., USHAM R. and KAMEL H: Preterm Prelabour Rupture of Membrane: 1 Year Study. Journal of Evolution of Medical and Dental Sciences, 4 (49): 8495-8598, 2015.

9- EMECHEBE C.I., NJOKU C.O., ANACHUNA K. and UDOFIA U.: Determinants and Complications of PreLabour Rupture of Membranes (PROM) At the University of Calabar Teaching Hospital (UCTH), Calabar, Nigeria.Scholars Journal of Applied Medical Sciences, 3 (5B): 1912-1917, 2015.

10- KOOK S.Y., PARK K.H., JANG J.A., KIM Y.M., PARK H. and JEON S.J.: Vitamin D-binding protein in cervicovaginal fluid as a non-invasive predictor of intraamniotic infection and impending preterm delivery in women with preterm labor or preterm premature rupture of membranes. PloS one, 13 (6): e0198842, 2018.

11- SAELIN P. and WANITPONGPAN P.: Incidence and risk factors of preterm premature rupture of membranes in singleton pregnancies at Siriraj Hospital. Journal of Obstetrics and Gynaecology Research, 45 (3): 573-577, 2019.

12- SIRAK B. and MESFIN E.: Maternal and perinatal outcome of pregnancies with PROM at Tikur Anbesa specialized teaching hospital. Ehtiop Med. J., 4: 52, 2014.

13- BOUVIER D., FOREST J.C., BLANCHON L., BUJOLD E., PEREIRA B., BERNARD N. and GIGUÈRE Y.: Risk Factors and Outcomes of Preterm Premature Rupture of Membranes in a Cohort of 6968 Pregnant Women Prospectively Recruited. Journal of Clinical Medicine, 8 (11): 1987, 2019.

14- EVEREST N.J., JACOBS S.E., DAVIS P.G., et al.: Outcomes following prolonged preterm premature rupture of the membranes. Arch. Dis. Child-Fetal Neonatal Ed, 93: F207-11, 2008

15- GABBE S.G., NIEBYL J.R. and SIMPSON J.L.: Obstetrics: Normal and problem pregnancies. ${ }^{5}$ ed: Ed: Churchill Livingstone, 2007.

16- ZHOU Q., ZHANG W., XU H., LIANG H., RUAN Y., ZHOU S. and LI X.: Risk factors for preterm premature rupture of membranes in Chinese women from urban cities. Int. J. Gynaecol. Obstet. Dec., 127 (3): 254-9, 2014.

17- DAIVA V., STAFAN B. and VIDAA M.: Antenatal risk factors associated with PPROM. Acta Medica Litutania, 9 (3), 2002.

18- CHOUDHARY M., RATHORE S.B., CHOWDHARY J. and GARG S.: Pre and post conception risk factors in PROM. Int. J. Res. Med. Sci., 3 (10), 2015.

19- ASSEFA N.E., BERHE H., GIRMA F., BERHE K., BERHE Y.Z., GEBREHEAT G. and WELU G.: Risk factors of premature rupture of membranes in public hospitals at Mekele city, Tigray, a case control study. BMC pregnancy and childbirth, 18 (1): 386, 2018.

20- KAYE D.: Risk factors for preterm premature rupture of membranes at Mulago Hospital, Kampala. East Afr. Med. J. Feb., 78 (2): 65-9, 2001.

21- WHYNOTT R.M., VAUGHT K.C.C. and SEGARS J.H.: The Effect of Uterine Fibroids on Infertility: A Systematic Review. Semin Reprod Med. Nov., 35 (6): 523, 2017.

22- MENON R. and RICHARDSON LS.: Preterm prelabor rupture of the membranes: A disease of the fetal membranes. Semin Perinatol. Nov., 41 (7): 409-419, 2017.

23- ROMERO R., MIRANDA J., CHAEMSAITHONG P., CHAIWORAPONGSA T., KUSANOVIC J.P., DONG Z., AHMED A.I., SHAMAN M., LANNAMAN K., YOON B.H., HASSAN S.S., KIM C.J., KORZENIEWSKI S.J., YEO L. and KIM Y.M.: Sterile and microbial-associated intra-amniotic inflammation in preterm prelabor rupture of membranes J. Matern Fetal Neonatal Med. Aug., 28 (12): 1394-409, 2015.

24- RONZONI S., D'SOUZA R., SHYNLOVA O., LYE S. and MURPHY K.E.: Maternal blood endotoxin activity in pregnancies complicated by preterm premature rupture of membranes. The Journal of Maternal-Fetal \& Neonatal Medicine, 32 (20): 3473-3479, 2019.

25- TCHIRIKOV M., SCHLABRITZ-LOUTSEVITCH N., MAHER J., BUCHMANN J., NABEREZHNEV Y., WINARNO A.S. and SELIGER G.: Mid-trimester preterm premature rupture of membranes (PPROM): Etiology, diagnosis, classification, international recommendations of treatment options and outcome. J. Perinat Med. Jul., 26; 46 (5): 465-488, 2018.

26- TENBRINK E.E., QUAIN A., DAGGY J., HAAS D.M. and SHANKS A.: Risk of Neonatal Sepsis with Rescue Steroids in Preterm Premature Rupture of Membranes versus Intact Membranes [25F]. Obstetrics \& Gynecology, 131, 70S, 2018 


\section{الإصابة وعوامل الخطر والنتائج للتمزق المبكر للأغشية للحامل: عبردراسية قسيم التمني}

الولادات المبكرة مسؤولة عن 27.0\% من وفيات الأطفال السنوية على مستوى العالم، و70.0\% من وفيات ما قبل الولادة فى البلدان المتقدمة و 50.0\% من الاضطرابات العصبية.

تشمل عوامل خطر الولادة ما يلى: عد م كفاءة عنق الرحم، والحمل المتعدد، ودورات الولادة المحدودة، وتاريخ الإجهاض، وتفكك الأغثية المبكر، والولادة المبكرة.

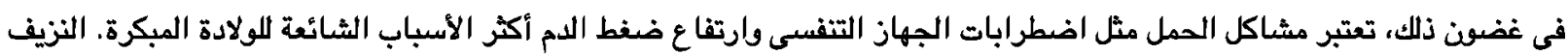
أثناء المخاض، نقص السائل الإمينوسى، تشوهات الجنين على وجه الخصوص وتشوهات الأعضاء المختلفة والجهاز العصبى المركزى.

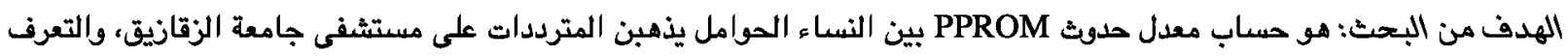

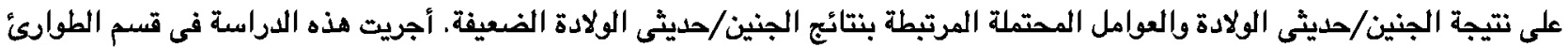

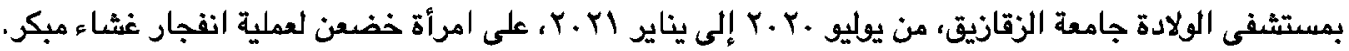
النتيجة: كانت عوامل الخطر الحالات كالتالى: 30 حالة لعدم وجود عامل خطر (12.7\%)، (12.7)، 16 حالة لتمزق الأغشية السابق المخاض (11.6\%)، 12 حالة للحمل المتعدد (8.7\%)، 24 حالة نزيف قبل الولادة (17.4\%).

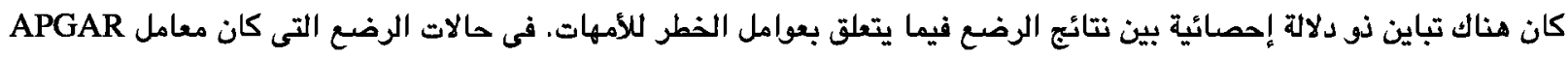

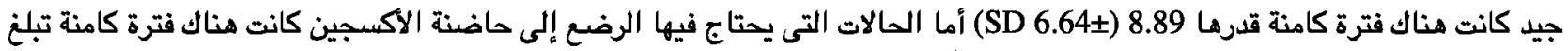

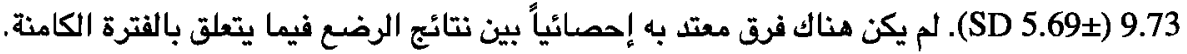

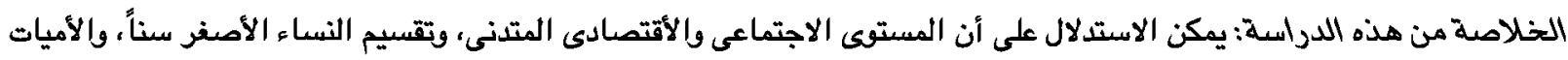

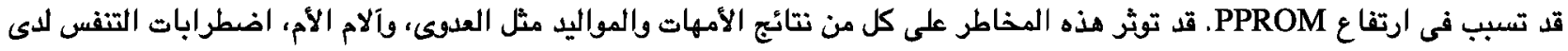

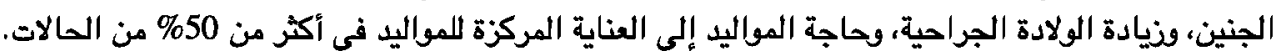

